\title{
Characteristics of East Asian Meditation
}

\author{
Halvor Eifring \\ University of Oslo
}

\begin{abstract}
The aim of this article is threefold: It attempts to 1) identify the characteristics of East Asian forms of meditation, as compared to meditation in other parts of the Eurasian continent; 2) test the usefulness of a definition of meditation as a self-administered technique for inner transformation; and 3) test the usefulness of a classification of meditation techniques based on generic features of the meditation object, in particular location (external vs. internal), agency (spontaneous vs. produced), and faculty (cognitive vs. sensory). While the variation among East Asian forms of meditation is considerable, they (along with Indic forms) are often more technical and less consistently devotional than their Western counterparts, and less often sound-based than their Indic counterparts. In a number of ways, both the definition and classification system suggested turn out to be helpful in the analysis of East Asian forms of meditation.
\end{abstract}

Keywords: meditation, mental attitude, meditation object, body, breathing, subtle body, visualisation, direct contemplation, keyword meditation, devotion 
This paper is an attempt at identifying major strands of East Asian meditation and trying to place them within a larger global context. ${ }^{1}$ What, if anything, is characteristic of East Asian forms of meditation, as compared to other meditative traditions? ${ }^{2}$

As so often, "global" means primarily Eurasian. As far as we know, meditative techniques are traditionally a peculiarity of Eurasian cultures, though the apparent lack of such traditions outside Eurasia may be due to the scarcity of written sources. Even within Eurasia, meditation is more often transmitted orally than in writing, so our historical knowledge of such techniques is only fragmentary. ${ }^{3}$

In Eurasia, meditative traditions are found within all larger and several smaller religions, including the following:

Judaism, Christianity and Islam (Middle Eastern origin; the monotheistic religions of the West)

Hinduism, Buddhism, Jainism and Sikhism (Indian origin)

Daoism, Confucianism and Shintoism (East Asian origin)

I will use the term "East Asian meditation" to refer to forms of meditation that have traditionally been widely used in China, Korea and/or Japan. This includes techniques developed and used within Daoism, Confucianism and Shintoism, as well as forms of Buddhist meditation that have been widespread in East Asia, including but not restricted to forms that were developed on East Asian ground.

A comparative approach to meditation necessitates the use of theory and terminology that are not restricted to any one specific cultural tradition, but are as neutral and descriptive as possible and make use of etic rather than emic categories. Actual comparison of

1 This article has profited from comments by Masaya Mabuchi and Mark Teeuwen.

2 The comparative study of meditation is a new field with few predecessors Goleman (1988) and Kohn (2008) are examples of popularised scholarship with a comparative aim. Brown (1986) compares Hindu and Buddhist techniques. This is also the main focus of Franco (2009), but it also includes studies of Christian and other traditions.

3 Scattered reports about indigenous Native American forms of meditation are probably correct, but more research is needed. 
meditative traditions, then, may be seen as providing test-cases for such theories and terminologies.

Another aim of this paper, therefore, is to use East Asian forms of meditation as a test ground for a definition of meditation and a system of classification. As a point of departure, therefore, we shall first look into problems of definition and classification.

\section{Definition}

One of the most central issues to resolve is the definition of meditation. As pointed out by Murphy \& Donovan (1997:2), "[t]he attempt to abstract out the primary characteristics of meditation from a grab bag of traditions in order to come to some purifie[d] essence or generic definition is a uniquely Western and relatively recent phenomenon". However, we need not look upon the definition of meditation as an attempt to arrive at a "purified essence", only a necessary heuristic step to provide us with a common ground for comparison. Such a definition is stipulative and makes no claim to identify the "real" meaning of the concept of meditation. Its usefulness will depend on the context in which it is used.

Due to the lack of comparative studies of meditation, few historical studies attempt to provide a definition that goes beyond any one particular tradition. A recent exception is the following definition by Kohn (2008: 1; forthcoming):

Meditation is the inward focus of attention in a state of mind where ego-related concerns and critical evaluations are suspended in favor of perceiving a deeper, subtler, and possibly divine flow of consciousness. A method of communicating with hidden layers of the mind, it allows the subconscious to surface in memories, images, and thoughts while also influencing it with quietude, openness, and specific suggestions.

This long-winded, though interesting account mentions a number of features that are typical of many, though hardly all, meditation techniques. Its operational usefulness, however, is limited, since it refers to notions that not only are hard to identify objectively, but may 
even prove to have limited intersubjective, not to speak of intercultural, value. What, for instance, is "a deeper, subtler, and possibly divine flow of consciousness"? Furthermore, by mentioning the influence of "specific suggestions" on the "subconscious", it refers to the author's highly controversial view of meditation as a form of selfhypnosis or self-suggestion.

The need for a generic definition of meditation has been felt more strongly in the sciences, where a variety of definitions has been discussed since the 1970s. After reviewing the literature and conducting an interesting study of the scientific concensus concerning meditation, Ospina et al. $(2007: 6$; 208) acknowledge that there still exists "a need to develop a consensus on a working definition of meditation applicable to a heterogeneous group of practices". The seven participants in their study agree, however, that a meditation practice includes the following "essential" elements:

[It] (1) uses a defined technique, (2) involves logic relaxation, and (3) involves a self-induced state/mode. (Ospina et al. 2007: B-2)

A number of other elements are considered "important", but not necessarily "essential" and should not be seen as parts of a definition.

It is debatable, however, to what extent this attempt at developing a definition of meditation is relevant to the concerns of this article. Rather, it reflects the ideas of only a handful North American scientists concerning criteria suggested in various scientific papers regarding forms of meditation that have been studied for health effects. While this is both useful and legitimate in and of itself, it is not directed to the needs of a cultural study of non-American meditative traditions in which health is at best a secondary concern. It is interesting to see, for instance, that although hardly a consequence of the definition above, the participants in the Ospina study almost unanimously reject visual techniques from the realm of meditation, while forms of visualisation are central to both Daoist and Tantric meditation practices.

In this paper, I will discuss each practice according to the following definition of meditation: 
Meditation is a self-administered technique for inner transformation.

How do various East Asian practices conform to this definition? And if they do not, should the definition be revised, or should the practices not count as meditative?

This definition has been developed within the Cultural Histories of Meditation project, conducted by myself at the University of Oslo, in collaboration with a number of scholars of Eastern as well as Western meditative traditions. It differs from both definitions above in not being based on any particular mental state(s), but rather on the long-term "transformation" (changes in trait rather than state ${ }^{4}$ ) sought by the meditator. While there are interesting similarities in the mental states involved in different meditation practices, short-term states are not a concern of all such techniques, and the states involved may differ from each other. As pointed out by Shapiro \& Walsh (1984: 6), for instance, not all meditation techniques are relaxing; they may instead have exciting or arousing effects. The focus on such long-term changes distinguishes meditation from many modern relaxation techniques, such as autogenic training and progressive muscle relaxation. ${ }^{5}$

My definition shares with both definitions above a focus on technique (or, in Kohn's terms, method), thus excluding what are often considered to be spontaneous meditative states. Its focus on the technique being self-administered reflects the same concern as the Ospina focus on a "self-induced state/mode". 6 The provision that meditation should involve "logic relaxation", or, in Kohn's terms, "a state of mind where ego-related concerns and critical evaluations are suspended", has been excluded, since it is debatable whether this is a necessary part of, for instance, devotional and recitative meditation.

4 Cf. Cahn \& Polich (2006).

5 Apart from inner transformation, meditation may of course also be used for a number of other purposes, including calm and relaxation, ritual purposes, providing others with auspicious "vibrations" etc. Such usages are not discussed in this paper.

6 For instance, Ospina et al. (2007: 22; 45) excludes "external Qi Gong” because it is based on a trained practitioner performing the method in order to help a patient rather than changing him- or herself. 


\section{Classification}

Another issue of central importance to the comparative study of meditation is that of classification. According to Ospina et al. (2007: 10), meditation has been classified according to "the primary goal of practice (therapeutic or spiritual), the direction of the attention (mindfulness, concentrative, and practices that shift between the field or background perception and experience and an object within the field), the kind of anchor employed (a word, breath, sound, object or sensation), and according to the posture used (motionless sitting or moving)". Kohn (2008:6) proposes to classify the various forms according to "the venue they use to access the subconscious mind", basically dividing all types into "visual, auditory, and kinesthetic".

If we look away from posture and goal of practice, these various ways of classifying forms of meditation refer to the mode and the focus of attention, both of which are considered central, or even defining, elements of meditative techniques.

The mode of attention during meditation may be referred to as mental attitude and is often discussed in terms of the Buddhist distinction between concentrative meditation (samatha 止) and insight meditation (vipassanā 觀), sometimes also involving the Buddhist notion of mindfulness (sati 正念). These terms, however, are in themselves highly ambiguous and should probably be replaced by more concrete and well-defined terms, such as degree of effort, open vs. closed field of awareness, acceptance vs. rejection of spontaneous thoughts etc. In this paper, I have chosen to look away from this aspect of meditation, not because it is unimportant, but because our historical sources are insufficient to make meaningful comparisons.

The focus of attention during meditation may be referred to as a meditation object. In this meaning, even many so-called "objectless" forms of meditation actually have an object, such as techniques focusing on the changing contents of the mind or on the sensation of the entire body. In other words, not all meditation objects are produced by the meditator, since some objects, such as breathing and body sensations, are spontaneous in the sense that they exist prior to the meditative practice. The classification of meditation techniques according to meditation object has been common at least since the 
fifth century Theravāda Buddhist work Visuddhimagga. Kohn's classification system is also based on meditation objects. The latter, however, only covers sensory distinctions among these objects, distinguishing visual, auditory and kinaesthetic (largely corresponding to tactile) forms. In addition, we need to recognise meditation objects that are not primarily sensory, but cognitive, involving conceptual, symbolic, and imaginative forms. Emotional objects, such as devotion, loving-kindness and the sense of guilt, may also be included. A further distinction into internal and external meditation objects is important, as many techniques involve the gradual interiorisation of the object, moving from an external physical object to a mental one and even further into a "higher" realm of "subtle" objects.

I suggest, therefore, that meditation objects may be classified according to the following criteria:

location: external vs. internal objects

agency: spontaneous vs. produced objects

faculty: cognitive vs. sensory objects

The choice of object will at least partly determine the outcome. Many meditation objects may involve elements from more than one group, such as the repetition of sounds (sensory) with a meaning (cognitive). Some techniques have both a primary meditation object, towards which the main focus of attention is directed, and one or more secondary objects, which constitute a background for the main practice.

\section{The history of East Asian meditation}

In the following, we shall try to provide an outline of East Asian forms of meditation, as a test case for the definition and classification above. Let us start with some brief and, needless to say, sweeping generalisations concerning the historical development of meditation in East Asia, in particular China.

The first identifiable period of East Asian meditation may be traced to the classical period of Chinese civilisation, roughly the first half millennium BC. Most of the thought systems that emerge in this 
period display a strong interest in self-cultivation, and some of them seem to have pursued this goal not only by means of moral education, but also by means of techniques resembling what we would call meditation. Much of the basic technical terminology of Chinese and East Asian meditation was developed in this period, including Mencius' “flood-like energy" (hàorán zhī qì 浩然之氣), Lăož̌s "holding on to the one" (bào yī 抱一) and "guarding tranquility" (shǒu jìng 守靜), Zhuāngž̌s “fasting of the mind” (xīnzhāi 心齋), "guarding the one" (shǒu (qi) y $y \bar{l}$ 守(其)一), "sitting in oblivion" (zuò wàng 坐忘), “following the median" (yuán dī 緣督), "guiding and stretching" (dăoy̌n 導引), "exhaling and inhaling" (tǔ [gù] nà [xīn] 吐[故]納[新]), “listening with one's qì energy" (tīng [zhī $y \grave{l}] q i$ 聽[之以]氣), and “heel breathing” (xi y̌ zhǒng 息以踵 [zhǒngxi 踵息]), as well as the virtually omnipresent notions of "energy" (qi 氣), “essence" (jīng 精), “spirit" (shén 神) and "self-cultivation" (xiū shēn 修身). The actual practices are not easily discernible from the texts themselves. Thus, in his analysis of the "Inward Training" 內業 chapter of the Guănž 管子, Harold Roth (1999) often needs to amend the text to support his assumption that the chapter deals with a kind of breathing technique. He sometimes assumes for no obvious reason that the term qi 氣 'cosmic and bodily energy' is used in its concrete sense 'air; breath', he sometimes adds "the breath" as an object where the original text has no object, and he reinterprets the well-known classical term yún qì 雲氣 'the clouds and the air [or possibly the energy of the clouds]' (which is found in Zhuāngž̌, often in connection with holy men riding the clouds) as yùn qì 運氣 'directing one's energies' (which is not found in any other classical text, but only appears later). ${ }^{7}$

The second period of East Asian meditation may be roughly located to the first half millennium AD. This is the period when a large repository of meditative techniques is imported into East Asia from India through Buddhism, and this is also the period when Daoist breathing techniques and methods of visualisation are described at

7 The interchangeable use of yùn 運 and yún 雲 is found in other texts as well, though later, as in the Bàopú ž̀ 抱樸子. 
length in a number of sources. ${ }^{8}$ It is uncertain to what extent the emergence of these Daoist techniques is a response to the influx of Buddhist meditation, and to what extent they are a domestic phenomenon, based on traditions that may have been inherited directly from the first period, as they themselves assume. There is no doubt that Buddhism made a strong impact on Daoism, but the Daoist techniques are very different from their Buddhist counterparts, and they also serve different aims.

After a transitory period, the third period of East Asian meditation starts roughly at the beginning of the second millennium AD. The partial replacement of Indian meditation with sinicised forms had taken place ever since the meditation manuals of Huìsi 慧思 and Zhìyi 智顗 in $6^{\text {th }}$-century Tiāntāi Buddhism, but the emergence of "silent illumination" (Mòzhào Chán 默照禪) and "keyword meditation" (Kànhuà Chán 看話禪) in eleventh-century Chán Buddhism marks an even more thorough departure from Indian models. ${ }^{9}$ In roughly the same period, Daoism witnessed the fruition of "inner alchemy" 內丹 (a term that may have been coined by the Buddhist Huìsī!), which combined old and new forms of meditation with a vocabulary modelled on alchemy; again this was only partly a response to Buddhism, most of the techniques being very different from Buddhist meditation, even when they had the same names, such as "inner contemplation" (nèiguān 內觀, see below). ${ }^{10}$ In this period, meditation also returned to Confucianism, especially with Zhū Xī's famous statement about "meditating half the day, and reading the other half" 半日靜坐, 半日讀書. As has often been pointed out, this was undoubtedly a response to the popularity of Chán. Confucianism did not, as far as I know, develop new forms of meditation, but placed old forms known from Buddhism and Daoism into radically new contexts. ${ }^{11}$ The same is probably true of Shintoism in Japan. ${ }^{12}$ further the Buddhist impulse. For Daoist works of this period, see Robinet (1993).

9 See, for instance, Schlütter (2008)

10 See the many works listed in Pregadio (2009).

11 Cf. Yáng Rúbīn \& Zhù Píngcì (2005). 
It is difficult to determine where to place the 500-year period between, roughly, AD 500 and $\mathrm{AD} 1000$. This was undoubtedly an important period for the development of East Asian forms of meditation. In some respects, it seems to be a continuation of the previous period, as in the Daoist practices associated with the Shàngqing 上清 tradition, or in the continued use of Indian Buddhist practices. In other respects, however, a new rhetoric of meditation is developing in the so-called Southern School of Chán, new forms of meditation are developed in the Tiāntāi tradition of Huìsī and Zhìȳ, and the idea of an "inner alchemy" (nèidān 內丹) is gradually emerging within Daoism. I have treated this period, therefore, as a transitional period.

Different forms of East Asian meditation are not only technically divergent, but also pursue widely different ultimate goals, including the longevity and eternal life of the Daoists, the Buddhists' departure from the wheel of life, the this-worldly moral progress of the Confucians, and the communication with and protection of the gods within Shintoism. What they do seem to have in common, however, is a wish to refine the mind of the practitioner. In this sense, most of them are indeed "self-administered techniques for inner transformation", as our definition of meditation states.

\section{Body and breathing}

From the very beginning, a large number of East Asian meditative techniques have made use of the body, and in particular breath, as objects of meditation. Though body-centred, such practices may still accord with our definition of meditation as techniques for inner transformation, since they involve a large number of mental functions (awareness, concentration, visualisation, mental control etc.). Also, many of the practices relate not only to the physical body, but to mental or spiritual entities assumed to belong to the so-called subtle 
body. Most importantly, these practices are assumed to have clear psychological and spiritual effects. However, the borderline between meditative techniques and pure body practices is not easy to draw. In this paper, I have excluded from our discussion techniques in which bodily movement is the primary focus of attention, as in tàiji quán 太極拳 and its many predecessors.

The focus on the body breaks blatantly with our classification of meditation objects into external vs. internal, spontaneous vs. produced, and cognitive vs. sensory. First of all, the body is both external (a physical object) and internal (belonging to the meditator) at the same time. Second, breathing and other bodily objects of meditation are located on the borderline between spontaneity and active production, since they are usually spontaneous, but may also be actively interfered with. Third, while breathing and other bodily functions are neither cognitive nor sensory, they may be accompanied by cognitive activities (such as the counting of in- and out-breaths), and sensory impressions (tactile or less often auditory impressions of the breath or other bodily functions). The ambiguous status of the body within the classification system, however, is not an argument against this system, but rather tells us why the body is such a popular object of meditation. Its potential as a meditation object is precisely due to its placement at the crossroads of some of the most central polarities within the meditative realm, and thus within human existence itself.

The centrality of the body varies a lot from one tradition to another, and from one technique to another. The strongest bodily concern is found in Daoist meditation, in which the preservation of the body - physical immortality - is often seen as the ultimate goal of meditation, mental refinement being largely a means to achieve this goal. In line with this orientation, the body, and especially the breath, is a primary meditation object in many Daoist techniques, since it is assumed to contain channels for the transmission of life-preserving cosmic energies. A similar concern with body and breath is found in Indian Yoga and Tantric Buddhism, none of which, however, aspires 
to achieve physical immortality. ${ }^{13}$ In non-Tantric Buddhist meditation, positive concern with the body is usually restricted to the use of the breath as a primary meditation object, helping to achieve meditative absorption, and the secondary, ancillary use of the lotus position or other postures as a bodily basis for successful meditation. In some forms of Buddhist meditation, such as Silent Illumination (Mòzhào 默照) and Just Sitting (Shi kan taza 只管打坐), the absence of a clearly defined primary object of meditation tends to increase the emphasis on this secondary object, with the result that it is sometimes treated as a primary object. Both body and breath are also used as primary objects of Buddhist meditation with a more negative focus, being prime examples of the impurity, emptiness and impermanence of human existence. Outside the East Asian context, the body (but not the breath) plays an important role in Islamic Dhikr, in which strong body movements often function as secondary meditation objects, while Christian meditative focus on the body is usually restricted to a negative concern with its filthiness or sinfulness or its ancillary use as a secondary object of meditation, e.g. with the folding of hands or, in the Eastern Orthodox Jesus Prayer or some of Loyola's spiritual exercises, with the breath as an ancillary element.

In many meditative traditions, the body may be looked upon as a concrete physical object (the coarse body) or as a semi-spiritual object (the subtle body), and both aspects of the body play a role in meditative traditions as different as Islamic Dhikr, Indian Yoga, Buddhist and Hindu Tantra, as well as Daoism and even Confucianism. The subtle body is typically connected not only to the physical body, but also to the geographical environment, to the physical universe, to divine realms and divinities, and to basic cosmic forces such as the Daoist jing 精 'essence', qi 氣 'energy' and shén 神 'spirit'. Various points in the body are often considered particularly important for meditation, viz. the cakras of Yoga and Tantra and the lower, middle and upper cinnabar fields (dāntián 丹田) of Daoism. In a few cases, the "meridians" (jīngluò 經絡) of Chinese medicine also 
have a place in the subtle body, as in some interpretations of Zhuāngzi’s concept of following the median (yuándū 緣督). In some traditions, the awareness (and often visualisation) of the subtle body may be accompanied and intensified by actual physical movements. Just as non-Tantric Buddhism and Christianity share with each other a more limited concern with the physical body, they are also much less concerned with the subtle body than most other meditative traditions.

The distinction between the coarse and the subtle body also applies to the breathing. The Chinese concept of qi and the Indian concept of prāna are both based on the common (coarse) breathing, but in their subtler forms denote energies that traverse not only the human body, but the entire universe. As far as I know, this concept is not a part of Islamic Dhikr, in spite of its strong focus on the subtle body. And again, it is neither part of Christian meditation nor, to any considerable extent, of non-Tantric Buddhism. It has, however, made its way into both classical Confucianism (as in Mencius's flood-like energy 浩然之氣) and the meditative practices of the NeoConfucians.

As mentioned above, the distinction between meditation and nonmeditational body techniques is gradient. Many traditions have alimentary regimes that are seen as helpful to meditation, but do not in themselves constitute meditation techniques, such as the avoidance of meat and alcohol, the intake of herbs and stimulants, the Daoist avoidance of grains, or other forms of fasting. Both Daoism and Tantrism employ sexual techniques to achieve similar aims as meditation, and the retention of semen (associated with life-giving forces) is common to both traditions. Daoism also practises the repeated swallowing of saliva with similar aims. Techniques in which body movement is a primary object, such as Hatha Yoga and Daoist qìgōng 氣功 and tàijí quán 太極拳, often practise forms of awareness that are close to meditation, and in Islamic Dhikr, where the main focus is mental, body movements have an important ancillary function.

In East Asia, body parts or body functions are used as meditation objects both in Buddhist (nèiguān 內觀 'inner contemplation', 
zhèngniàn 正念 'mindfulness') and Daoist (shǒuȳ 守一 'guarding the one', nèiguān 內觀 'inner contemplation', nèishì 內視 'inner vision') forms of meditation. In both traditions, awareness is sometimes directed in a neutral way towards certain body parts, often though not always with an element of concentration and active avoidance of spontaneous thoughts. In addition to whatever calm this brings about, the Daoist focus is often on the retention of various types of $q i$ 氣, while the Buddhist focus tends to be on the training of mindfulness, as well as the realisation of the impurity, emptiness and impermanence of the body - and, by inference, of human existence.

While the body parts themselves are spontaneous objects of meditation, towards which the meditator directs his attention without adding or subtracting anything, both Daoism and some forms of Yoga and Tantra supplements this awareness with active visualisation. For instance, Daoist meditation supplements the awareness of the five viscera (wǔ zàng 五臟) with their active visualisation, and, especially in the Shàngqing tradition, even with the interior visualisation of divinities with which they are associated. ${ }^{14}$ Active visualisation of the body is, to my knowledge, not part of non-Tantric Buddhism.

A similar contrast exists between the neutral observation of spontaneous breathing (as in the most common form of Buddhist mindfulness meditation) and, for instance, the specified forms of exhalation associated with Daoist tǔnà 吐納 'exhaling and inhaling' meditation (chui 吹, $h \bar{u}$ 呼, $x \bar{\imath}$ 唏, $h \bar{e}$ 呵, $x \bar{u}$ 噓 and $x i$ 呬), the direction of the breathing away from the respiratory organs to other parts of the body in Daoist embryonic breathing (tāixi 胎息, breathing with the navel or the entire body) and heel breathing (zhóngxi 踵息), or the expansion of the respiratory system from the nose to the lungs and then to the lower abdomen (in practice using the breath to push the diaphragm downwards). The manipulation of $q i$ 氣 inside the body, in order to avoid congestion that hinders the free flow of bodily energies, known as directing one's energy (yùnqi 運氣, also called xíngqi 行氣, yinqii 引氣, tōngqi 通氣, bìqi 逼氣, biqqi 閉氣), also most often has as 
its point of departure the actual inhalation of air. This also often involves attempts at increasing the amount of inhaled air and reducing the amount of exhaled air.

The awareness of the breath may be directed towards the tip of the nose (as is very common in Buddhist meditation) or any other part of the respiratory system, and quite often towards the lower abdomen. This awareness is usually tactile, but in Daoist "listening to one's breath" (tīng xí 聽息) it may also be auditory (though aiming at a perception that transcends the sensory organs). In Buddhist mindfulness training, the breathing is often accompanied by the cognitive act of counting (mentally or aloud).

In sum, Daoist meditation resembles Yoga and Tantra in its active approach to body and breathing, while non-Tantric Buddhist meditation is much less concerned with both. While non-Tantric Buddhist meditation is primarily concerned with the body and the breath as they are by themselves, without manipulation, Daoism, Yoga and Tantra includes a large number of exercises in which body and breath are actively manipulated. With regard to body, but not to breath, the same is true of Islamic Dhikr. Daoism, Yoga, Tantra and Dhikr are also strongly concerned with the subtle body, and, with the exception of Dhikr, with the subtle breath. However, Daoism differs from Yoga, Tantra and Dhikr in having physical longevity or even physical immortality as its primary aim, and there are also considerable technical differences. To my knowledge, for instance, Daoism has no counterpart to the Yogic and Tantric attempts at using the breath as a means for elevating bodily energies from the lower points in the subtle body to the higher ones (and, conversely, Yogic and Tantric techniques do not have the idea of circulation so central to some Daoist techniques), and it has no counterpart to the Yogic and Tantric focus on the "emptiness" between inhalation and exhalation.

\section{Visualisation}

Visualisation, and the closely related practice of imagination, is employed by most meditative traditions, but in very different ways. The following are some examples: 
1. Narratives: Loyola's spiritual exercises are concerned with visualising stories from the Bible, in order to intensify the contemplation of the meaning of the narrative. The scenes visualised relate to ordinary people (if the apostles can be termed as such) in often quite quotidian situations.

2. Diagrammes: In Tantric traditions, the interiorisation of mandalas and yantras is used for meditation. While mandalas typically combine concrete images of Buddhas, deities, beasts etc. with a specified geometric representation of the cosmos, yantras usually come closer to being purely geometric diagrammes without natural images. ${ }^{15}$

3. Light: In some Yogic traditions, the visualisation of light is used as a meditative object, sometimes starting with a burning candle as an external meditation object, then closing the eyes and interiorising this image, until in the end only the sense of light is left; at other times directing the attention to inner impressions of light without going through the steps of interiorisation or active imagination. ${ }^{16}$

4. Objects of devotion: In non-Tantric Buddhism, visualisation is primarily used in connection with images of Buddhas, bodhisattvas, and objects of symbolic meaning, such as lotus blossoms.

5. Inner and outer universe: In mediaeval Daoism, visualisation of the body, especially the five viscera (wǔ zàng 五藏), is combined with the visualisation of deities, cosmic transformations, as well as stars and planets, including imagining oneself travelling in space. The aim is not devotional, but rather to connect the energies of the individual to the energies of cosmos, breaking through all blockages both within and outside the body.

In terms of our classification, these forms all make use of sensory meditation objects, relying on the sense of vision, but most of them also have a strong cognitive element, focusing on narrative, symbolic or other forms of meaning. With the possible exception of some of the meditations on inner light, these meditation objects are produced

15 See Tucci (1973) and Khanna (2003).

16 See Bäumer (2008: 84ff.). 
rather than spontaneous. In most forms, the objects involved may be either external (mandala and yantra paintings, burning candles, sculptures or paintings of devotional objects, flags with paintings of Daoist gods etc.) or internal. Again, therefore, the categories of our classification system are partly broken down.

Not all imagination is visual. Strictly speaking, Loyola's spiritual exercises are often imaginational rather than visual, since they may also include the imagination of auditory, tactile and other impressions associated with the stories in focus. In the Tantric tradition, the practice of creative contemplation (bhāvanā) is, in a sense, imaginational, but is hardly visual. ${ }^{17}$ Typical examples of this type involve the imagination of one's body and the space surrounding it as complete emptiness. In comparison, Daoist visualisation is fairly straightforward. In spite of the long stretches of imagination involved, and the enormously detailed specifications of the images, these exercises remain surprisingly concrete and, in an extended sense of the word, material.

The use of the character guān 觀 'to watch; to see; to contemplate' reveals a basic difference between (non-Tantric) Buddhism and Daoism. In the former, the character is used for any kind of contemplative awareness, regardless of which sense is involved, while in the latter (especially before the rise of Inner Alchemy), it is primarily used in its concrete visual sense, more or less synonymous to shi 視, kuì 窥 and kàn 看 'to look; to see'. Thus, while both Buddhism and Daoism have meditative practices termed "inner contemplation" (nèiguān 內觀), the Buddhist practices usually consist of directing one's awareness towards spontaneous aspects of the body, breath or mind and often have nothing to do with the sense of seeing, while the Daoist variants are most often linked to visualisation (also termed "inner vision" nèishì 內視). ${ }^{18}$ As we have seen, visualisation is also found in (non-Tantric) Buddhism, then often termed guānxiăng 觀想 ‘to watch and think' or, even more concretely, guānxiàng 觀像 'to watch an image'. But compared to Daoism, visualisation here plays a fairly minor role and is mainly associated with the devotional

17 Bäumer (2008: 33f.).

18 See Sakade (1991), Kohn (1989). 
orientation of Pure Land Buddhism. In Daoism, on the other hand, visualisation is a primary form of meditation. Although meditation on body and breath may in practice assume equal importance, some Daoist traditions treat them as preparatory and auxiliary exercises and place the primary focus on its rich inventory of visualisation techniques.

\section{Devotion}

Devotion is not only a feature of all major Eurasian forms of religion, but is also a very common element in their meditative practices. In the monotheistic religions originating in the Middle East (Judaism, Christianity, Islam), devotional and faith-based meditation is the dominant form, and its formless contemplation of God or Allah is often virtually indistinguishable from so-called mystical prayer. But devotional forms of meditation are also common in South and East Asia, as in the repetition of God's name (nam simran) in Sikhism, as well as the worship of İ́vara in Yoga and of Amitābha Buddha in Pure Land Buddhism.

The borderline between meditation on the one hand and ritual and prayer on the other is often hard to draw. Devotional meditation is often less obviously technical in its approach than other forms of meditation, since it relies just as much on the establishment of a relation between the meditator and the object of meditation as on the objective effect of the technical elements of the practice. Devotional meditation, therefore, often accords less obviously with the definition of meditation as a technique.

While popular Daoist religion is full of devotional ritual and prayer, Daoist meditation seldom seems to be devotional. The vast vistas of divine lands and beings that are often parts of Daoist visualisation techniques are not primarily produced for the sake of devotion, but for the opening up of energy channels between the body, the physical universe and cosmic forces from the godly realms. The closest we get to devotional meditation is the attempts at invoking protective spirits, such as the five heraldic animals associated with the five viscera. In the mediaeval Shàngqīng tradition, however, devotion 
may also have been at least a part of the meditative practice. ${ }^{19}$

In Buddhism, devotional meditation is widespread, but tends to be associated with the Pure Land school and its variants of "recitation of the Buddha's name" (or "mindfulness of the Buddha", niàn fó 念佛), and therefore with the worship of Amitābha Buddha. The repeated recitation or chanting of "Namo Amitābha Buddha" (in its East Asian equivalents) may form the basis for communal ritual, individual prayer, and silent meditation. Mental repetition, as in silent meditation, is often considered to be more difficult, but also more efficacious than oral repetition. In many ways, this practice resembles japa, the repetition of a mantra, in the Hindu tradition, which may also be used for communal ritual, individual prayer, and silent meditation. However, while japa also has its devotional aspects, each mantra typically being associated with a Hindu god, its effect is to a much larger extent seen to depend upon the sound as sound, not as a linguistic sign for the object of devotion. In this respect, the repetition of "Namo Amitābha Buddha" is more similar to the Jesus prayer in Eastern Orthodox Christianity, in which a formula like "Lord Jesus Christ, have mercy on me" is repeated vocally or mentally by the practitioner, and the Shinto recitation of the prayer "Distant gods, please bless us; exorcise [evil from us], purify us". ${ }^{20}$ Of course, both the Jesus prayer and the Shinto prayer are explicit prayers in the petitional sense, the practitioner begging for mercy or for blessings and purifications, while "Namo Amitābha Buddha" is just a devotional salutation (though also often used with petitional purposes, since its proper recitation is seen as a means to secure rebirth in the Pure Land of the West). Like the Jesus prayer, which may be expressed in any language, the formula "Namo Amitābha Buddha", though based on Sanskrit etymons, has different versions in different languages, and in contrast to Hindu mantras, there is little attempt at retaining the original Sanskrit pronunciation, cf. Chinese Námó Amituó Fó, Korean Namu Amita Bul, and Japanese Namu Amida $B u t s u$. The arbitrary form of the linguistic sign is even more obvious in salutations to bodhisattvas that have Chinese names, as in the case

19 Robinet (1993: 74).

20 Tohokami emitame haraitamai kyometamai 吐菩加美依身多女袚賜比清女給比, see Sawada (1998: 113). 
of Avalokiteśvara, whose salutation in Chinese is Námó Guānshìȳn Púsà rather than the Sanskrit Namo Avalokiteśvara Bodhisattva. Thus, while the mantras repeated in japa are strongly sound-centred, with at best a weak link to semantic or symbolic content, the formulas repeated in devotional meditation are primarily meaning-centred, the phonetic form of the formula being just as arbitrary as in ordinary language. This even applies to the repeated vocal or mental recitations of Islamic Dhikr, which, though based on Arabic formulae that may not be translated into other languages, still is primarily meaningoriented and devotional. In our classification system, mantra meditation is primarily sensory, while devotional repetition is primarily cognitive, the sense of devotion itself belonging to the emotional (and therefore in a wide sense cognitive) realm. ${ }^{21}$ In many traditions, however, there is a vacillation between the two forms. Stephen H. West (2000) shows how both semantic and mantric readings of the Heart Sūtra were present in traditional China, and Mark Teeuwen (personal communication) points out how reciting the Heart Sūtra in its Sino-Japanese (and to most practitioners unintelligible) pronunciation in Japan achieves a mantric effect. The same may be said about the use of Latin in modern Catholic contexts, as well as the modern use of Aramaic phrases like maran ata 'the Lord comes' or mara nata 'come the Lord' for Christian meditation.

Buddhist devotional meditation is not restricted to the repetition of linguistic formulae. As mentioned above, the visualisation of Buddhas, bodhisattvas and Buddhist symbols like the lotus also play an important role. Other forms of contemplation of Buddhas and bodhisattvas are also important, including presumably advanced forms that equate the meditator (or his mind) with the object of meditation, and forms that seek a formless Buddha (wú xiàng niàn fó 無相念佛 'formless mindfulness of the Buddha'), beyond linguistic or imagistic

21 Kohn (2008: 55) places the "chanting" of Pure Land recitation of the Buddha's name in the same category as the repetition of mantras. The distinction between the two is gradient, as there also exist mantric traditions that emphasise the semantic content of the mantra and Pure Land traditions that emphasise the sound quality of whatever is repeated. In the nineteenth century, the Muruyama 丸山 religion of Japan analysed each syllable of Namu Amida Butsu symbolically, similar to the symbolic interpretations of the sounds or syllables of mantras in the Indic tradition (Sawada 1998: 121). 
form. Thus, Buddhist devotional meditation resembles Christian devotional meditation in making use of both language and imagery, but also in often seeking a higher contemplation of its object beyond these forms. The variety of devotional meditation again makes it clear that the cognitive content is more important than the sensory form of its meditation objects.

\section{Direct contemplation}

Several meditative and mystical traditions have an ambiguous attitude towards the use of meditation techniques. In the Christian tradition, Meister Eckhart speaks of the "pathless path" (der weglose Weg), Kashmiri Shaivism speaks of the an-upaya "no means" way to liberation, Buddhist sources talk about the "gateless gate" (wú mén zhī mén 無門之門), and Lăožr's Dàodé jīng 道德經 begins with the assertion that "the way that can be told is not the permanent way" (道可道非常道). In modern times, Krishnamurti famously broke with his preordained role as spiritual leader by proclaiming that "the truth is a pathless land". If meditation is a technique, as our definition suggests, then these sources seem to express a deep skepticism towards meditation as such.

In Chán Buddhism, the idea of sudden enlightenment (dùnwù 頓悟) made all talk of gradual cultivation methods look suspicious. One response to this skepticism was the emergence of the Silent Illumination (mòzhào 默照) of Hóngzhì Zhèngjué, in which all methods are said to be dispensed with. In line with this, the writings of Hóngzhì himself read as poetic descriptions of a specific frame of mind rather than practical and methodical advice on how to establish this mental state. Possibly, however, this kind of direct contemplation may be interpreted as a kind of mindfulness or awareness training, the practitioner bringing his mind back with full awareness to whatever situation he is in whenever he discovers that it has wandered away into distracting thoughts.

In spite of their non-technical nature, Hóngzhì's writings have 
inspired centuries of methodical practice in one of East Asia's great meditative traditions, the Sitting Meditation (zuò chán 坐禪) of the Cáodòng 曹洞 school of Chán. The Just Sitting (shi kan taza) 只管打坐 method of its most important interpreter, the Japanese master Dōgen 道元 is not much more specific about technical matters, but places great emphasis on the sitting and the awareness of the body. ${ }^{22}$ Again, it is not always clear that his practice may count as a technique and thus as meditation in our sense of the term.

In the modern Buddhist master Shèngyán's 聖嚴 interpretation, the direct contemplation of Hóngzhì and Dōgen involves a method with different stages of gradually increasing awareness: 1) awareness of the body, 2) awareness of the mind, 3) full awareness. Each stage may even be split into smaller constituents, distinguishing, for instance, the awareness of the body from the awareness of the breath. ${ }^{23}$ In this interpretation, the differences between Silent Illumination and other kinds of Buddhist mindfulness or awareness training are maybe less substantial than the rhetoric surrounding them sometimes indicate. Shèngyán's explication of this method may be read as its gradual technification or methodification, a process that may indeed have started already with Dōgen's student Keizan 瑩山.

Not all forms of direct contemplation imply a skepticism towards fixed methods. In Kashmiri Shaivism, for instance, an-upaya "nomeans" may be viewed as the highest way to liberation, but the tradition's vast array of meditation techniques receives almost equal respect. In Meister Eckhart, the skepticism is not directed towards meditation methods, which are hardly a topic in his sermons, but against intellectual attempts at pinning down the nature of God. To the extent that there is a skepticism towards fixed methods in Hóngzhì and his followers, it may be understood as a reaction against the excessive reliance on the mechanical effects of a technical approach to meditation rather than a reaction against meditation as such. The gradual development of methods built on Hóngzhì's dispensal with method may be less paradoxical than it first seems. In modern 
contexts, one often sees how Hóngzhì's Silent Illumination and Dōgen's Just Sitting are supplemented with technical elements like the attention to breathing or to the lower abdomen (Japanese hara 腹). ${ }^{24}$

Silent Illumination seems to provide the most radical break with our classification system, since at the outset it makes no use of a specific meditation object at all, just directing the attention to whatever situation one is in. However, the tendency over the centuries has been to specify the focus of awareness more narrowly, first to the body (or breath), then to the activities of the mind, only gradually arriving at the wide and open focus of Hóngzhì's Silent Illumination. If we define a meditation object as "the focus of awareness during meditation", then Silent Illumination, as expounded by Shèngyán, moves from a bodily to a mental and then to a combined externalinternal object. All the way, the object is spontaneous, not produced. Also, there is no specification of whether the object should be cognitive or sensory, or both at the same time.

Both in Buddhism and other traditions, meditation is actually often described in similarly semi-technical or even non-technical terms as Silent Illumination. The entering into dhyanna or samādhi in early Buddhist sources is only sometimes described as the effect of a technique, at other times it is described as a spontaneous or willed change in state of mind. Similar descriptions of dhyāna and samādhi are common within the Yoga and Tantra traditions.

It is possible to interpret early Daoist approaches to meditation in a similar way. The gradual dispensal with ordinary consciousness and emergence of deeper realisation in Zhuāngž̌s "sitting in oblivion" (zuò wàng 坐忘), the sublimation of sensory perception into a consciousness grounded in "emptiness" ( $x \bar{u}$ 虛) in Zhuāngž̌'s "fasting of the mind" (xīnzhāi 心齋), and the tranquilising of the mind in Lăož̌'s "guarding tranquility" (shǒu jìng 守靜) may have been the effects of specific techniques, but there is little textual evidence for this, and they may just as well have been varieties of direct contemplation. 
The relative lack of a technical focus is even more evident in Christian meditation. The word meditation is often used in the Christian tradition to denote a stronger reliance on scripture than what is commonly associated with meditation in other traditions. However, what is often referred to as mystical prayer often involves the silent contemplation of an impersonal God beyond words and images. I have noted above the similarities of this form of meditation with Buddhist devotional meditation, such as "mindfulness of the formless Buddha" (wú xiàng niàn fó 無相念佛), but there is also a strong resemblance to the Silent Illumination of Chán.

\section{Keyword meditation}

A very different response to the methodical vacuum left behind by the Chán emphasis on sudden enlightenment is the meditation on “keywords” (huàtóu 話頭; gōng'àn 公案, often known in the West by the Japanese term kōan) developed by Dàhuì Zōnggāo 大慧宗杲 and others before and after him. Filling the discursive mind with stories, questions and phrases that do not have an obvious meaning or answer on the discursive level is meant to exhaust the mind in its attempts at finding such meaning or answers, and to fill the mind with an existential doubt that in the end can lead to the awakening of a deeper, non-discursive insight into the basic nature of self (zixing 自性) and the Buddha (fóxing 佛性).

The proponents of keyword meditation, including Dàhuì, often inherited from the early advocates of "sudden enlightenment" (such as Shénhuì 神慧) a strong antagonism towards seated meditation, in Dàhuì's case taken to refer to the Silent Illumination of Hóngzhì. The mind's concerted efforts to discover the nature of the mind were seen as futile, and the use of keywords was designed to break down such concerted efforts. It could be practised not only while sitting, but also while walking, standing and lying down. Sometimes sitting was even strongly discouraged, for fear that it would lead to a passive and withdrawn attitude. In spite of this, however, Dàhuì was the pioneer of 
a form of seated form of keyword meditation that is still widely used, associated with the Línjì 臨濟 (Japanese Rinzai) school of Chán 禪 (Japanese Zen). This form of meditation is clearly a self-administered technique used to achieve inner transformation, which accords well with our definition. Keyword meditation also provides a strong argument against taking relaxation as an essential element of meditation, since the reported initial effect of its intense concentration and existential doubt is to make the meditator tense rather than calm, and since the calm sitting of Silent Illumination was seen as excessively quietistic. On the other hand, even in keyword meditation, the eventual enlightenment ostensibly produces a sense of relief that may produce at least momentary calm.

The attempt at reaching beyond the discursive mind is not specific to keyword meditation, but is common to a large number of meditative and mystical traditions, including approaches as different as Zhuāngžı's Daoism and Meister Eckhart's views of God. The attempt at reaching an insight into the basic nature of the self is also not particular to keyword meditation, but is common to most Indianderived forms of meditation, with the possible exception of Theravāda Buddhism. What sets keyword meditation apart from all other traditions, however, is its reliance on stories, questions and phrases as meditation objects for these purposes.

Narrative stories are also used as meditation objects in Christian mysticism, such as the spiritual exercises of Loyola, but then with a less anti-discursive aim. Christian meditation attempts to arrive at a still largely cognitive understanding of the stories themselves rather than using the stories to reach behind such meaning.

In our classification system, keywords are cognitive meditation objects, but unlike other cognitive meditation objects, they are used to actively break down the cognitive grid of the mind. They rely more strongly on semantic content than on phonetic form, but in the end even their semantic content dissolves. While keyword meditation aims at producing a strong emotional reaction in the form of basic doubt, this feeling is an effect rather than a part of the meditation object itself, unlike the sense of devotion in typical devotional forms of meditation. 


\section{Conclusion}

Do East Asian forms of meditation, then, share important characteristics that distinguish them from other meditative traditions? I think the discussion above shows two things with reasonable clarity:

1. The variation within East Asian forms of meditation is so considerable that we are hard put to find traits that characterise these forms as a whole.

2. Almost all types of East Asian meditation resemble in form types of meditation from traditions outside East Asia.

Meditations on different aspects of body and breath, visualisation techniques, devotional meditation, and direct contemplation are common not only in East Asia, but also in a number of other traditions. Only keyword meditation and its use of stories, questions and phrases to create doubt, tear apart our habitual cognitive web and open the mind for deeper insights seems to be exclusively East Asian.

Most East Asian forms of meditation are self-administered techniques for inner transformation and therefore fall neatly within our definition. Their degree of "logic relaxation" varies from the radical breakdown of cognitive structures in keyword meditation to the milder, emotional and often symbol-oriented forms of meditation in devotional forms of meditation. In some traditions, there is a strong concern with mental states, while other traditions explicitly deny the relevance of such short-term changes. Some techniques, in particular keyword meditation, are geared towards tension rather than calm.

A distinction that has so far only been hinted at, but not yet explicated is the one between a magico-mythological approach and a more neutralist approach to meditation. This distinction also cuts across the borderline between East Asia and the rest of the Eurasian continent. The two approaches are typically characterised by the presence (magico-mythological) or the absence (neutralistic) of the following features:

- a rich inventory of mythological beings (gods, demons, suprahumans, beasts etc.) 
- a strong cosmic orientation, relating to spiritual forces in the entire universe

- a strong interest in the body, especially forces associated with the subtle body, but sometimes also including physical or imagined sexuality

- the importance of visualisation techniques

- the frequent use of magical spells and a strong interest in magical transformations

In East Asia, the most typical example of a magico-mythological approach is Daoism, with Shingon and possibly Tendai and Nichiren in Japan as a small branch of a large Tantric area that includes Tibetan Buddhism and a considerable part of Indian religion. In the monotheistic religions, Judaic Kabbalah is probably the most typical example. In East Asia, both (non-Tantric) Buddhism and especially Confucianism show a certain (though far from unequivocal) tendency towards neutralism, as do the dominant forms of the monotheistic religions of the West.

Another distinction hinted at is the varying degrees of technical orientation in the different meditative traditions. Among the main types of meditation discussed above, both devotional meditation and direct contemplation tend to be only loosely technical, the former being closely related to prayer and ritual, and the latter seeking to establish a direct and unmediated contemplative frame of mind, beyond technical or methodical considerations. The scriptural and purgational forms of meditation common in Judaism and Christianity are also at best semi-technical. Furthermore, magico-mythological approaches often make a less clearcut distinction between ritual and meditation than more neutralistic approaches do. In general, methods of meditation with a strong technical element are further developed in India and East Asia than in the monotheistic religions of the West. It is only in India and East Asia, for instance, that we find primary meditation objects that are cognitively relatively neutral, such as body and breath, and sensory objects like mantras and yantras. As we have seen, however, even India and East Asia have strong meditative traditions in which the methods employed are only loosely technical. 
Map: Three areas of meditative traditions

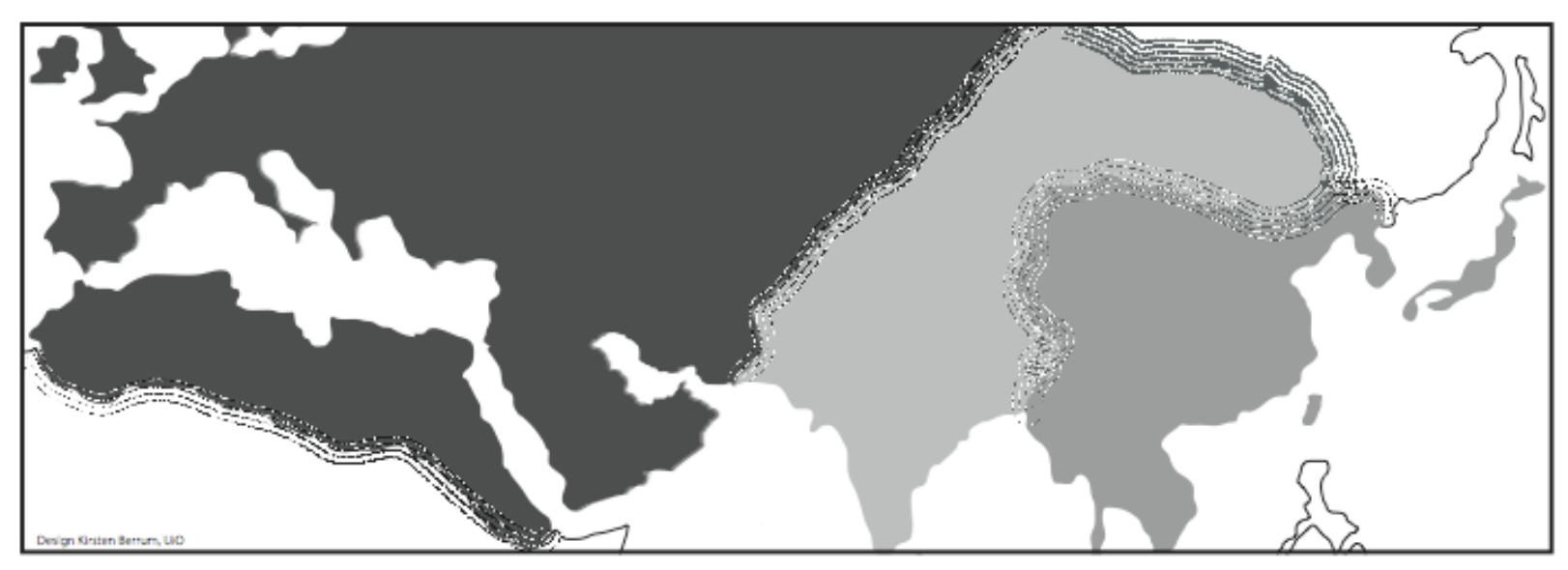

Western, relatively non-technical, strong focus on devotion Indic, relatively technical, strong focus on sound

East Asian, relatively technical, weak focus on sound 
Indian (including Tibetan) and East Asian approaches to meditation are largely overlapping, but by no means identical. One of the most conspicuous differences is the prominence of sound-based meditation in the Indian tradition, contrasted with its virtual absence in East Asia. Buddhist mantras and Daoist magic spells play a central role in East Asian rituals, such as the morning and evening recitations at temples, but their role in meditation is at best minor (with the possible exception of Shàngqing Daoism), in strong contrast to the omnipresence of japa meditation in India. This may be explained by the relative lack of Tantric elements in East Asian Buddhism (apart from Japanese Shingon, Tendai and Nichiren), but it may also be an effect of the different role of sound in the two cultures. Despite the vast number of languages on the Indian subcontinent, the attempts at preserving a "correct" Sanskrit pronunciation has undoubtedly increased the cultural sensitivity towards sound, and although Indian culture has traditionally been skeptical towards writing, the fact that its writing systems are based on phonetic principles has also undoubtedly helped to increase sound consciousness. In contrast, the Chinese writing system makes it natural to disregard phonetic differences between its various historical and geographical variants. The mantras used in East Asian Buddhist rituals today have a completely domestic phonetic make-up, employing sounds and sound combinations that would hardly be considered "mantric" in an Indian setting. The minor role of mantra and other sound-based forms in East Asian meditation may also be seen in conjunction with the even more peripheral role of yantra, geometric diagrammes that function as visual meditation objects. Thus, both auditory and visual meditation objects play a more important role in Indian meditation than in East Asian forms. Note, finally, that even Western traditions, despite their lack of technical orientation, sometimes pay more attention to phonetic shape than the East Asian traditions do, as when the mediaeval English work The Cloud of Unknowing recommends the use of a monosyllabic word like "God" or "love" as an object of meditation.

Finally, let us return to the classification of meditation objects presented at the beginning of this paper: 
external vs. internal objects

spontaneous vs. produced objects

cognitive vs. sensory objects

To what extent are these three criteria central in distinguishing different forms of meditation from each other?

At first glance, the first criterion seems irrelevant, since all the different forms of meditation have both external and internal variants, except for body meditation, which is located on the borderline between external and internal. However, within each type, the contrast between external and internal objects is often recognised as a central distinction, internal objects being almost consistently considered to be more difficult, but also more effective than external objects. Many types of meditation typically involve a movement from the external towards the internal, such as the movement from a burning candle to inner sensations of light. Even body meditation often involves such a movement, moving from the coarse body to the subtle body.

The second criterion is of obvious importance. Body meditation may be based on spontaneous objects (such as natural breath) or produced objects (e.g. the production of special breathing patterns), while visualisation, devotion and keyword meditation are usually based on produced objects, and the object of direct contemplation, if any, is spontaneous. The awareness of spontaneous breathing, body sensations or mental fluctuations plays an important role in Buddhist mindfulness training, and the distinction between so-called concentrative meditation (samatha) and insight meditation (vipassanā), which plays such an important role in Theravada Buddhism, is partly based on the same criterion.

The third criterion has been shown to be important for the proper understanding of the distinction between mantra meditation (which has a predominantly sensory focus) and devotional repetition (which has a predominantly cognitive focus). Many forms of meditation combine cognitive and sensory elements, but there are also more or less pure types, such as the mindfulness of breathing in Buddhism (sensory) or, if we venture outside East Asia, the scriptural meditations of Judaic and Christian mysticism (cognitive). Sensory objects of meditation play a much less central role in the monotheistic religions of the West than in India and East Asia, probably due to their 
less technical approach to meditation.

In sum, the three criteria outlined point to central variations within the field of meditation, both within and outside East Asia.

\section{Bibliography}

Bäumer, Bettina (2008): Vijñāna Bhairava: Das göttliche Bewußtsein. Frankfurt: Verlag der Weltreligionen.

Bielefeldt, Carl (1988): Dōgen's Manuals of Zen Meditation. Berkeley, CA: University of California Press.

Brown, Daniel (1986): "The Stages of Meditation in Cross-Cultural Perspective”. In: Ken Wilber, Jack Engler \& Daniel Brown eds., Transformations of Consciousness and Contemplative Perspectives on Development. Boston, MA: Shambhala, pp. 219 283.

Cahn, B. Rael, and John Polich 2006. "Meditation States and Traits: EEG, ERP, and Neuroimaging Studies." Psychological Bulletin, 132.2, pp. 180-211.

Franco, Eli ed. (2009): Yogic Perception, Meditation and Altered States of Consciousness. Vienna: Austrian Academy of Sciences Press.

Goleman, Daniel (1988): The Meditative Mind: The Varieties of Meditative Experience. New York, NY: Tarcher/Putnam.

Khanna, Madhu 2003: Yantra: The Tantric Symbol of Cosmic Unity. Rochester, VT: Inner Traditions.

Kohn, Livia (1989): "Taoist Insight Meditation: The Tang Practice of Neiguan." In Livia Kohn (ed.): Taoist Meditation and Longevity Techniques. Ann Arbor, MI: University of Michigan, Center for Chinese Studies, pp. 193-224.

Kohn, Livia (2008): Meditation Works: In the Daoist, Buddhist, and Hindu Traditions. Magdalena, NM: Three Pines Press. 
Kohn, Livia (forthcoming 2010): Sitting in Oblivion: The Heart of Daoist Meditation. Dunedin, FL: Three Pines Press.

Loori, John Daido (2004): The Art of Just Sitting, Second Edition: Essential Writings on the Zen Practice of Shikantaza. $2^{\text {nd }}$ edition. Somerville, MA: Wisdom Publications.

Murphy, Michael \& Steven Donovan eds. (1997): The Physical and Psychological Effects of Meditation: A Review of Contemporary Research with a Comprehensive Bibliography 1931-1996. Sausalito, CA: Institute of Noetic Sciences.

Ospina, Maria B. et al. (2007): Meditation Practices for Health: State of the Research. Rockville, MD: Agency for Healthcare Research and Quality.

Pregadio, Fabrizio (2009): Chinese Alchemy: An Annotated Bibliography of Works in Western Languages. Golden Elixir Press.

Robinet, Isabelle (1993): Taoist Meditation: The Mao-shan Tradition of Great Purity. Albany, NY: SUNY Press.

Roth, Harold (1999): Original Tao: Inward Training and the Foundations of Taoist Mysticism. New York, NY: Columbia University Press.

Sakade, Yoshinobu (1991): "Methods and Ideas on Increasing Vitality in Ancient China: The Transition from Neiguan to Neidan in the Sui and Tang Dynasties." In Yoshio Kawakita, Shizu Sakai, and Yasuo Otsuka, eds.: History of Hygiene: Proceedings of the 12th International Symposium on the Comparative History of Medicine-East and West. Tokyo: Ishiyaku EuroAmerica, pp. 99115.

Samuel, Geoffrey (2008): The Origins of Yoga and Tantra: Indic Religions to the Thirteenth Century. Cambridge: Cambridge University Press. 
Sawada, Janine Anderson (1998): "Mind and Morality in $19^{\text {th }}$-Century Japanese Religions: Misogi-kyō and Maruyama-kyō". Philosophy East \& West 48.1, pp. 108-141.

Schlütter, Morten (2008): How Zen Became Zen: The Dispute over Enlightenment and the Formation of Chan Buddhism in SongDynasty China. Honolulu, HI: University of Hawai'i Press.

Shapiro, Deane H. \& Roger N. Walsh eds. (1984): Meditation: Classic and Contemporary Perspectives. New York, NY: Aldine.

Sheng Yen (2008): The Method of No-Method: The Chan Practice of Silent Illumination. Boston, MA: Shambhala.

Tucci, Giuseppe (1973): The Theory and Practice of the Mandala. New York, NY: Samuel Weisner.

West, Stephen H. (2000): "Heart Sūtra". In Pauline Yu, Peter Bol, Stephen Owen \& Willard Peterson (eds.): Ways with Words: Writing about Reading Texts from Early China. Berkeley, CA: University of California Press, pp. 121-129.

Yang Rubin 楊儒賓 \& Zhu Pingci 祝平次 eds. (2005): Rúxué de qilùn yǔ gōngfūlùn 儒學的氣論與工夫論. Taipei: Guólì Táiwān Dàxué Chūbăn Zhōngxīn 國立台灣大學出版中心. 